\title{
Studies of the Pituitary-Leydig Cell Axis in Young Men with Hypogonadotropic Hypogonadism and Hyposmia: Comparison with Normal Men, Prepuberal Boys, and Hypopituitary Patients
}

\author{
C. Wayne Bardin, Griff T. Ross, Arleen B. Rifkind, Charles M. Cargille, and \\ MORTIMER B. LIPSETT \\ From the Endocrinology Branch, National Cancer Institute, National Institutes \\ of Health, Bethesda, Maryland 20014
}

\begin{abstract}
A в S T R A C T Pituitary and gonadal function was studied in seven chromatin-negative men, ages 15-27 yr, with retarded sexual and somatic development, skeletal anomalies, and hyposmia. These hyposmic patients were compared with normal men, prepuberal boys and hypogonadal patients with hypopituitarism. The urinary follicle-stimulating hormone ( $\mathrm{FSH}$ ) and luteinizing hormone ( $\mathrm{LH}$ ) levels of hyposmic subjects were the same as those of normal boys and hypopituitary patients but significantly lower than those of normal men. Clomiphene citrate did not cause an increase in plasma FSH and LH levels in either hypogonadal group as it does in normal men. In contrast to hypopituitary patients, thyroid and adrenocortical function and release of growth hormone in the hyposmic subjects were normal. The plasma testosterone levels were equally low in prepuberal, hypopituitary, and hyposmic patients but were increased to a greater extent by human chorionic gonadotropin (HCG) treatment in prepuberal and hypopituitary subjects than in the hyposmic patients. Prolonged treatment with HCG has failed to return plasma testosterone levels to normal in two hyposmic patients. These observations suggest that there are defects of both pituitary and Leydig cell function in men with the syndrome of hypogonadism, skeletal anomalies, and hyposmia. They have impaired secretion of FSH and $\mathrm{LH}$ and a Leydig cell insensitivity to gonadotropin.
\end{abstract}

A preliminary report of this work was presented at the combined meeting of The American Society for Clinical Investigation and The American Federation for Clinical Research, 5 May 1968.

Dr. Rifkind's present address is The Rockefeller University, New York 10021.

Received for publication 25 March 1969.

\section{INTRODUCTION}

Defective olfaction has been noted in patients with hypogonadotropic hypogonadism for many years. This association has been reported in individual patients (1) and in members of several kindreds (2-4). Despite the early recognition of patients with these signs, only with the recent development of precise methods for estimation of plasma androgens and gonadotropins have studies of the pituitary-Leydig cell axis of these patients been possible. To better understand this type of hypogonadism, the dynamics of gonadotropin and testosterone secretion were studied in seven males with hypogonadotropic hypogonadism and hyposmia. Comparable studies were carried out in normal men and in two other groups of hypogonadal subjects: "normal" prepuberal boys and patients with hypopituitarism.

\section{METHODS}

Methods were as follows: total urinary gonadotropins (5); urinary 17 -hydroxysteroids (6) ; plasma cortisol (7) ; plasma leutinizing hormone $(\mathrm{LH})(8)$; plasma follicle-stimulating hormone (FSH) (9); plasma growth hormone (10); and plasma testosterone (11). Urinary $\mathrm{FSH}$ and $\mathrm{LH}$ excretion were measured in normal men and children by bioassay (12, 13) of extracts of large pools of urine (14). Since we showed subsequently that $\mathrm{LH}$ and $\mathrm{FSH}$ activity in urine extracts could be estimated by radioimmunoassay $(9,15)$ on aliquots of a single $24 \mathrm{hr}$ collection, we measured the urinary LH and FSH excretion of hypopituitary and hyposmic patients by radioimmunoassay.

The sensitivity of $\mathrm{LH}$ and FSH radioimmunoassays are 6 and 4 in $\mathrm{mIU} / \mathrm{ml}$ respectively. ${ }^{1}$ As a consequence, potency

\footnotetext{
${ }^{1}$ Plasma and urinary $\mathrm{LH}$ and FSH levels are expressed in terms of milliInternational Units of the Second International Reference Preparation of human menopausal gonadotropin (IRP $2 \mathrm{HMG}$ ). For plasma values, $1 \mathrm{IU}$ of IRP $2 \mathrm{HMG}$ is equivalent to 50 and $21 \mu \mathrm{g}$ of LER 907, for FSH and LH respectively.
} 
estimates at low levels of $\mathrm{LH}$ and FSH in plasma are not reliable. In plasma a $20 \%$ difference is needed to distinguish $(P<0.05)$ two values ( $\mathrm{LH}$ or $\mathrm{FSH})$ from one another. Mean plasma FSH concentrations in samples from 30 normal men were $9.6 \mathrm{mIU} / \mathrm{ml}$ with $95 \%$ confidence limits of 8.0 $11.1 \mathrm{mIU} / \mathrm{ml}$. Mean $\mathrm{LH}$ concentrations in samples from 27 of them was $17.8 \mathrm{mIU} / \mathrm{ml}$ with $95 \%$ confidence limits of $15.7-19.9 \mathrm{mIU} / \mathrm{ml}$.

Tests of hypothalamic-pituitary and testicular function were performed as follows: a bacterial pyrogen ${ }^{2}$ was given intravenously at $0.6 \mu \mathrm{g} / \mathrm{kg}$ and blood obtained at $0,1,2$, and $4 \mathrm{hr}$. A normal response is defined as a doubling of plasma cortisol concentrations and an increase of plasma growth hormone to greater than $10 \mathrm{~m} \mu \mathrm{g} / \mathrm{ml}$ (16). Arginine ${ }^{8}$ (500 $\mathrm{mg} / \mathrm{kg}$ ) was infused for $0.5 \mathrm{hr}$ and plasma obtained at 30 -min intervals for $1.5 \mathrm{hr}$ after the end of the infusion. In normal subjects plasma immunoreactive growth hormone levels increased to $10 \mathrm{~m} \mu \mathrm{g} / \mathrm{ml}$ or more (17). Insulin, 0.1 $\mathrm{U} / \mathrm{kg}$ intravenously in normal subjects, increased plasma growth hormone to at least $10 \mathrm{~m} \mu \mathrm{g} / \mathrm{ml}$ when the blood sugar decreased $50 \%$. Clomiphene citrate was given by mouth $200 \mathrm{mg}$ daily for 6 days and induced mean increases of 160 and $130 \%$ in plasma LH and FSH levels respectively in normal men $(18,19)$. Human chorionic gonadotrophin (HCG), (APL, Ayerst Laboratories, New York), $4000 \mathrm{U}$ intramuscularly daily for 4 days, caused at least a $100 \%$ increase in plasma testosterone levels in normal men (20). Metyrapone, $750 \mathrm{mg}$ every $4 \mathrm{hr}$, caused a doubling of urinary 17-hydroxycorticoids in normal subjects. Except for the last, these tests have been standardized in this laboratory in normal men, ages 21-45 yr.

Hyposmic patients. Seven male subjects, ages 15-27 yr, with hyposmia and hypogonadism were studied. They were referred to our clinic because of retarded sexual development and a eunuchoidal habitus. All had clinically evident hyposmia, and there was difficulty with recognition of a variety of substances such as coffee, wintergreen, and cloves. Two subjects had nerve deafness, and one of them was color-blind. The karyotype was $46, \mathrm{XY}$ and the nuclear sex was chromatin negative in all seven subjects. Short fourth metacarpals were present by X-ray examination in four patients. The testes were either high in the inguinal canal or within the abdomen in four of the patients. Testicular biopsy was performed in all patients. The hyposmic patients had no family history of hypogonadism, and from a total of 15 siblings (10 sisters, five brothers), six women and two men were fertile. Pertinent clinical and laboratory features of each case are given in the Appendix and in Table I.

Hypopituitary patients. Eight patients (ages 6-47) with presenting complaints of growth failure, hypogonadism, or suspected pituitary tumor were referred to the Endocrinology Clinic. Each was clinically hypogonadal, had low urinary gonadotropin titers, and either low basal levels or defective release of at least one other pituitary hormone (Table II). Studies of gonadal function were performed when the patients were receiving necessary adrenal or thyroid replacement therapy.

"Normal" boys. Five prepubertal boys were evaluated because of short stature or cryptorchidism. Anterior pituitary function was normal, and the hypogonadism was judged to be compatible with the prepubertal state. Although these boys

\footnotetext{
${ }^{2}$ Piromen, purified Pseudomonas polysaccharide pyrogen, Travenol Laboratories, Morton Grove, Ill.

${ }^{3}$ Bulk 1, arginine- $\mathrm{HCl}$ from Schwarz Bio Research, Inc., was prepared in concentrations of $12.5 \mathrm{~g} / 100 \mathrm{ml}$ of hypotonic Ringers solution.
}

are not representative of the normal population, they have been included for comparison with the other hypogonadal groups. Pertinent clinical and laboratory findings are presented in Table III.

\section{RESULTS}

Studies of gonadotropin secretion. Urinary LH and FSH excretions in hyposmic patients ( $\mathrm{LH}, 0.88 \pm 0.24$, $\mathrm{SE} ; \mathrm{FSH}, 1.5 \pm 0.39 \mathrm{IU} /$ liter) were significantly less $(P<0.01)$ than those of normal men $(\mathrm{LH}, 4.7 \pm 0.6$; FSH, $5.6 \pm 1.0 \mathrm{IU} /$ liter) (Fig. 1). The gonadotropin concentrations in urine of normal children ( $\mathrm{LH}, 0.44$ \pm 0.7 ; FSH, $2.2 \pm 0.4$ IU/liter) and hypopituitary patients ( $\mathrm{LH}, 0.65 \pm 0.3$; FSH, $1.5 \pm 0.63 \mathrm{IU} /$ liter) were the same as those of the hyposmic patients. No single estimation of urinary $\mathrm{LH}$ or FSH from any of these three groups of hypogonadal subjects was in the range of eugonadal adult men. Plasma LH and FSH concentrations for hyposmic and hypopituitary patients ranged from below the sensitivity of the assays into the normal range (Tables I and II). It is thus apparent that with the techniques employed in this study, the hypogonadal groups were distinguished from normal men by specific urinary rather than plasma gonadotropin assays.

When clomiphene citrate was given to these patients, plasma $\mathrm{LH}$ increased in only one hyposmic and one hypopituitary subject (Figs. 2 and 3 ), and these increases were less than normal. Plasma FSH was not increased by clomiphene in either group (Figs. 2 and 3 ). Therefore, adult men were distinguished from the hypogonadal subjects by the response of plasma gonadotropins to clomiphene.

Studies of plasma testosterone. In normal men plasma testosterone levels range from 0.4 to $1.0 \mu \mathrm{g} / 100 \mathrm{ml}$ mean $(0.73 \pm 0.05 \mathrm{sE}, \mu \mathrm{g} / 100 \mathrm{ml})$ and increase $100 \%$ during HCG administration. In Fig. 4 the response of plasma testosterone to HCG in hyposmic subjects is compared with that of normal men. In six of the seven hyposmic subjects the plasma testosterone levels ranged between 0.02 and $0.04 \mu \mathrm{g} / 100 \mathrm{ml}$ and increased only slightly with HCG (Fig. 4). In one hyposmic patient (No. 4) the control plasma testosterone level was $0.2 \mu \mathrm{g} / 100 \mathrm{ml}$ and increased to control normal with HCG. This patient was the only one whose $\mathrm{LH}$ level increased slightly in response to clomiphene (see Appendix, patient No. 4).

Although testosterone response to HCG in hyposmic patients was significantly less than normal, it seemed pertinent to compare the HCG responsiveness in these subjects with that of other hypogonadotropic patients (Figs. 5 and 6). "Normal" boys had control plasma testosterone levels comparable to those of the hyposmic subjects and in the range for prepuberal boys reported by others (21). The mean increase of plasma testosterone during HCG administration was significantly greater $(P<0.05)$ in normal boys $(0.33 \pm 0.04[\mathrm{sE}] \mu \mathrm{g} / 100 \mathrm{ml})$ 
TABLE I

Clinical and Laboratory Features of Patients with

\begin{tabular}{|c|c|c|c|c|c|c|c|c|c|c|}
\hline \multirow[b]{2}{*}{ No. } & \multirow[b]{2}{*}{ Patient } & \multirow[b]{2}{*}{ Age } & \multirow{2}{*}{$\begin{array}{l}\text { Bone } \\
\text { Age }\end{array}$} & \multirow[b]{2}{*}{ Height } & \multirow[b]{2}{*}{ Span } & \multirow[b]{2}{*}{ Bony anomalies } & \multirow{2}{*}{$\begin{array}{l}\text { Total urinary } \\
\text { conadotropins }\end{array}$} & \multicolumn{3}{|c|}{ Urinary } \\
\hline & & & & & & & & LH & & FSH \\
\hline & & $y r$ & $y r$ & $\mathrm{~cm}$ & $\mathrm{~cm}$ & & $M U / d a y^{*}$ & $I U /$ liter & & $U /$ liter \\
\hline 1 & J. S. & 15 & 12.5 & 154 & 151 & 一 & $<10$ & - & & - \\
\hline 2 & D. F. & 18 & 14.5 & 150 & 155 & $\begin{array}{l}\text { Short } 4 \text { th metacarpals } \\
\text { Spina bifida } \\
\text { Hypoplasia 1st rib }\end{array}$ & $\begin{array}{l}<10 \\
>10<50\end{array}$ & $1.2 \pm 0.1$ & 0.35 & \pm 0.02 \\
\hline 3 & H. C. & 20 & 16 & 164 & 178 & Short 4th metacarpals & $<10$ & $0.95 \pm 0.08$ & 2.1 & \pm 0.1 \\
\hline 4 & P. H. & 21 & 16 & 141 & 147 & $\begin{array}{l}\text { Short } 4 \text { th and } 5 \text { th } \\
\text { metacarpals }\end{array}$ & $\begin{array}{l}<10 \quad(4) \\
>10<50 \quad(2)\end{array}$ & - & & - \\
\hline 5 & N. W. & 22 & 16 & 184 & 186 & Short 4 th metacarpals & $<10$ & $1.2 \pm 0.2$ & 2.0 & \pm 0.1 \\
\hline 6 & R. S. & 23 & 20 & 170 & 175 & $\begin{array}{l}\text { Fibrcus dysplasia of } \\
\text { sphenoid }\end{array}$ & $\begin{array}{l}<10 \\
>10<50\end{array}$ & $0.18 \pm 0.01$ & 1.3 & \pm 0.1 \\
\hline 7 & H. R. & 27 & 15 & 172 & 173 & Osteoporcsis & $\begin{array}{l}<10 \quad(16) \\
>10<50(6)\end{array}$ & - & & - \\
\hline No & nal men & & & & & & $50-200$ & $4.7 \pm 0.6$ & 5.6 & \pm 1.0 \\
\hline
\end{tabular}

LH, leuteinizing hormone; FSH, follicle-stimulating hormone; C, control ; P, Piromen test; ITT, insulin tolerance test; ATT, arginine tolerance test; PBI, protein-bound iodine test.

* Number of days at this level.

‡ These patients had a normal response to metyrapone.

$\S$ Normal response given in Methods.

and in hypopituitary patients $(0.40 \pm 0.16)^{4}$ than in hyposmic subjects $(0.09 \pm 0.04)$ (Fig. 5). Even though the hyposmic patients were similar to normal boys with respect to gonadotropin excretion and other tests of pituitary function, their Leydig cells were relatively insensitive to acute HCG administration.

Six hyposmic patients were treated with HCG (2000 12,000 IU/wk) for 3-8 months (See Appendix). Patient Nos. 2 and 5 had no objective clinical response to prolonged HCG treatment, and in patient No. 5 the plasma testosterone level rose to only $0.23 \mu \mathrm{g} / 100 \mathrm{ml}$ after 5 months of therapy. ${ }^{5}$ Patient Nos. 3 and 6 had minimal clinical responses to long term HCG, and plasma testosterone levels increased to $0.038 \mu \mathrm{g} / 100 \mathrm{ml}$ in patient No. 6 during this therapy. Patient Nos. 1 and 7 had good clinical responses to HCG treatment on more than one occasion, but plasma testosterone levels are not available.

Histopathological studies. Histologic features of the testes of the hyposmic patients were similar to those of prepubertal boys. In five patients histological examination

\footnotetext{
${ }^{4}$ Since the variances of the two groups were different a logarithmic transformation was employed to reduce variance and permit statistical evaluation of the means.

${ }^{B}$ Plasma testosterone levels after long-term HCG were determined by Dr. Marvin Kirschner.
}

revealed small seminiferous tubules which were lined by Sertoli cells and spermatogonia. In patient No. 5 there were a few primary spermatocytes. In patient No. 3

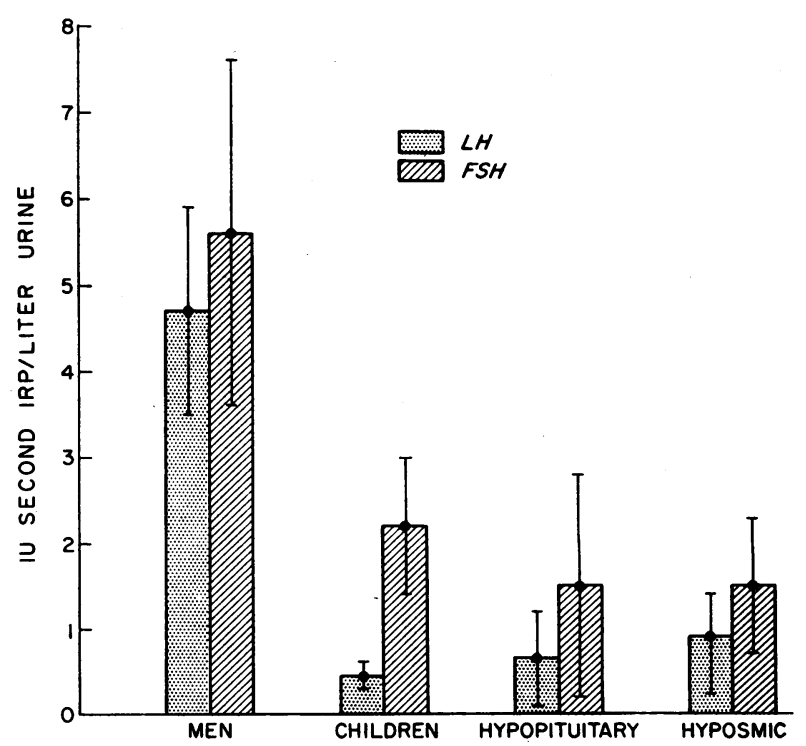

FIGURE 1 Urinary leuteinizing hormone (LH) and folliclestimulating hormone (FSH) levels in normal men and three groups of hypogonadal suspects. Mean $\pm 2 \mathrm{SE}$. The values for normal men and children have been reported previously (14). 
Hypogonadotropic Hypogonadism and Hyposmia

\begin{tabular}{|c|c|c|c|c|c|c|c|c|c|c|c|c|}
\hline \multicolumn{2}{|c|}{ Plasma LH } & \multicolumn{2}{|c|}{ Plasma FSH } & \multicolumn{2}{|c|}{$\begin{array}{l}\text { Plasma test- } \\
\text { osterone }\end{array}$} & \multicolumn{4}{|c|}{ Plasma growth hormone } & \multicolumn{2}{|c|}{$\begin{array}{l}\text { Plasma } \\
\text { cortisol }\end{array}$} & \multirow[b]{2}{*}{ PBI } \\
\hline $\mathrm{C}$ & phene & $\mathrm{C}$ & phene & $\mathrm{C}$ & HCG & C & $\mathbf{P}$ & ITT & ATT & c & $\mathbf{P}$ & \\
\hline \multicolumn{2}{|c|}{$m I U / m l$} & \multicolumn{2}{|c|}{$m I U / m l$} & \multicolumn{2}{|c|}{$\mu \mathrm{g} / 100 \mathrm{ml}$} & \multicolumn{4}{|c|}{$m \mu g / m l$} & \multicolumn{2}{|c|}{$\mu \mathrm{g} / 100 \mathrm{ml}$} & $\stackrel{\mu \mathrm{g} /}{100 \mathrm{ml}}$ \\
\hline 14 & - & - & - & 0.05 & 0.08 & 一 & - & - & 一 & $6 t$ & - & 6.6 \\
\hline 8 & 8 & 4 & 5 & 0.03 & 0.05 & 4 & 11 & 22 & 一 & 4 & 23 & 5.7 \\
\hline 11 & 10 & 5 & 4 & 0.06 & 0.09 & 6 & 18 & - & - & 9 & 28 & 5.5 \\
\hline 11 & 15 & $<6$ & $<6$ & 0.20 & 0.49 & 2 & 21 & - & - & 5 & 21 & 6.3 \\
\hline$<6$ & $<6$ & $<6$ & $<6$ & 0.05 & 0.08 & 4 & 18 & - & - & $4 \ddagger$ & 20 & 6.0 \\
\hline 12 & 9 & 7 & $<6$ & 0.02 & 0.13 & 1 & 21 & 10 & 20 & 10 & 21 & 7.3 \\
\hline \multirow[t]{2}{*}{6} & 6 & 4 & 4 & 0.04 & 0.08 & 1 & 10 & 10 & 12 & $5 \ddagger$ & 13 & 7.4 \\
\hline & $\S$ & & $\S$ & 0.70 & $\S$ & $0-6$ & & $\S$ & $\S$ & $5-15$ & $\S$ & $4-8$ \\
\hline
\end{tabular}

spermatogenesis was more advanced with normal numbers of spermatocytes and rare spermatozoa. In all patients Leydig cells were either rare and poorly developed or unidentifiable. A typical biopsy specimen is shown in Fig. 7.

\section{DISCUSSION}

According to De Morsier defective olfaction accompanying hypogonadism was noted as early as 1850 (22). In 1944 Kallman and associates (2) reviewed the earlier reports of this association and emphasized its hereditary aspects by describing three involved kindreds. Some of the patients described by these investigators had color blindness, synkinesia, mental retardation, and nerve deafness in addition to anosmia and hypogonadism. In recent years additional kindreds and individual patients with hypogonadism and defective olfaction have been reported $(1,3,4)$. In the present series, no family history of hypogonadism could be elicited, but a high incidence of extragenital and extragonadal anomalies were noted. All our patients had hyposmia (rather than anosmia) as did the members of the family described by Henkin (23). In addition to this sensory defect, color blindness and nerve deafness were present in two. Four patients had undescended testes, and four had short fourth metacarpals.
In addition to the hyposmic patients described above there are several syndromes in which secondary hypogonadism may occur in association with a variety of neurological and somatic abnormalities. In the LaurenceMoon Biedl syndrome, mental retardation, retinitis pigmentosa, and many other anomalies occur in a familial pattern with hypogonadotropic hypogonadism $(24,25)$.

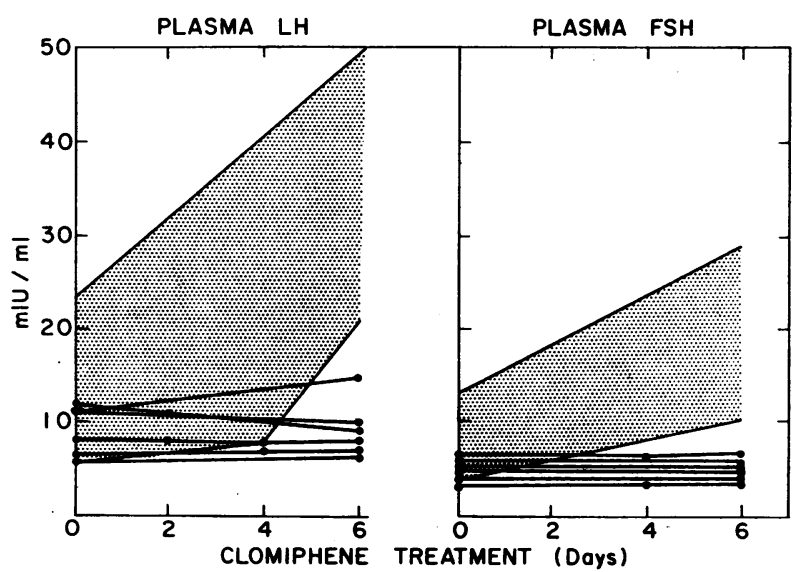

FIGURE 2 The plasma levels of LH and FSH in hyposmic patients before and during administration of clomiphene. The range of the responses in normal men are given by the shaded areas. 
TABLE II

Clinicalland Laboratory Features

\begin{tabular}{|c|c|c|c|c|c|c|c|}
\hline \multirow[b]{2}{*}{ No. } & \multirow[b]{2}{*}{ Patient } & \multirow[b]{2}{*}{ Age } & \multirow[b]{2}{*}{ Diagnosis } & \multirow[b]{2}{*}{ Clinical features } & \multirow{2}{*}{$\begin{array}{l}\text { Total urinary } \\
\text { gonadotropins }\end{array}$} & \multicolumn{2}{|c|}{ Urinary } \\
\hline & & & & & & $\mathrm{LH}$ & FSH \\
\hline & & & & & $M U / d a y^{*}$ & $I U /$ liler & $I U /$ liter \\
\hline 8 & R. L. & 6 & Histiocytosis-X & $\begin{array}{l}\text { Diabetes insipidus } \\
\text { Growth failure }\end{array}$ & $\begin{array}{l}<10 \quad(4) \\
>10<50 \quad(2)\end{array}$ & 一 & 一 \\
\hline 9 & L. D. & 14 & $\begin{array}{l}\text { Idiopathic hypo- } \\
\text { pituitarism }\end{array}$ & Short stature & $\begin{array}{l}<10 \\
>10<50\end{array}$ & - & 一 \\
\hline 10 & R. P. & 15 & $\begin{array}{l}\text { Idiopathic hypo- } \\
\text { pituitarism }\end{array}$ & Short stature & $\begin{array}{l}<10 \\
>10<50(1) \\
>50<200(1)\end{array}$ & $1.3 \pm 0.2$ & $3.4 \pm 0.2$ \\
\hline 11 & R. K. & 16 & $\begin{array}{l}\text { Chraniopharan- } \\
\text { gioma }\end{array}$ & $\begin{array}{l}\text { Diabetes insipidus } \\
\text { Short stature }\end{array}$ & $\begin{array}{l}<10 \quad(4) \\
>10<50(8) \\
>50<200(1)\end{array}$ & $0.02 \pm 0.01$ & $0.48 \pm 0.04$ \\
\hline 12 & R. M. & 16 & $\begin{array}{l}\text { Idiopathic hypo- } \\
\text { pituitarism }\end{array}$ & Short stature & $<10$ & $0.94 \pm 0.14$ & $1.2 \pm 0.14$ \\
\hline 13 & C. A. & 23 & Suprasellar tumor & $\begin{array}{l}\text { Short stature } \\
\text { Hypogonadism }\end{array}$ & $\begin{array}{l}<10 \\
>10<50\end{array}$ & $0.35 \pm 0.08$ & $0.92 \pm 0.03$ \\
\hline 14 & L. V. & 46 & Pituitary tumor & $\begin{array}{l}\text { Hypogonadism } \\
\text { Visual field defect }\end{array}$ & $\begin{array}{l}<10 \quad(1) \\
>10<50(8) \\
>50<200(3)\end{array}$ & - & 一 \\
\hline 15 & J. M. & 47 & Pituitary tumor & Hypogonadism & $\begin{array}{l}>10<50(4) \\
>50<200(3)\end{array}$ & 一 & 一 \\
\hline
\end{tabular}

C, control ; HCG, human chorionic gonadotrophin; P, Piromen test; ITT, insulin tolerance test; ATT, orginine tolerance test ; PBI, protein-bound iodine test.

* Number of days assayed at this level.

$\ddagger$ Normal response to metyrapone.

Similarly, familial cerebellar ataxia has been associated with nerve deafness and secondary hypogonadism (26, 27). Although not described as part of cerebellar ataxia or the Laurence-Moon-Biedl syndrome, short fourth metacarpals were present in the X-rays of such patients $(24,27)$. Hypogonadotropic hypogonadism has also been associated with other familial diseases such as diabetes mellitus and hyperlipemia (28). Even though patients with gynecomastia, hypoandrogenization, and low gonadotropin excretion may have a primary defect of gonadotropin production, increased blood estrogens could also produce these same clinical and laboratory findings (29); a clomiphene stimulation test should be useful in this distinction. To further add to the heterogeneity of these syndromes, primary hypogonadism has also been described in patients with Laurence-Moon-Biedl syndrome (29) and familial ataxia (30).

Kallman et al. (2) felt that the most reasonable genetic explanation for the association of gonadal and other developmental defects in eunuchoidal patients was breakage and partial translocation of the $\mathrm{X}$ chromosome not determinable by morphological examination. Such a defect could affect not only the genes carried on the $\mathrm{X}$ chromosome but also genes controlling sex via the auto-

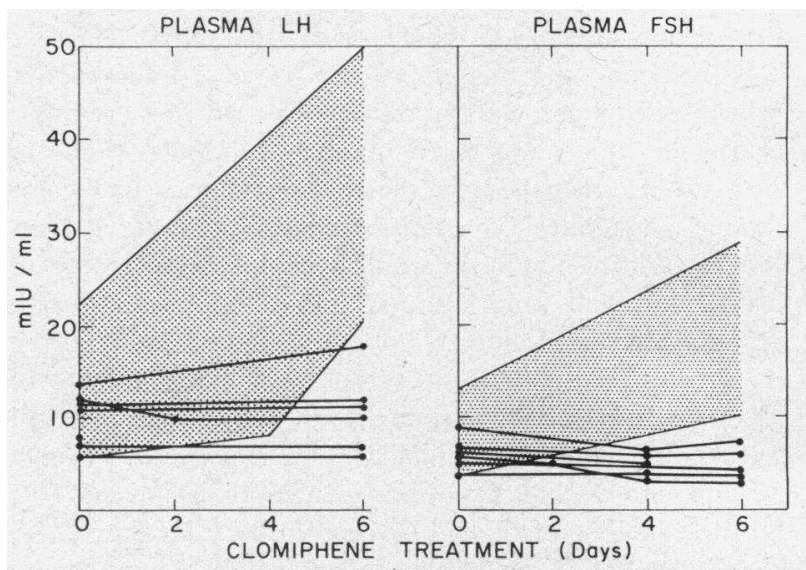

Figure 3 The plasma levels of $\mathrm{LH}$ and FSH in hypopituitary patients before and during clomiphene administration. The range of the responses in normal men are given by the shaded areas. 


\begin{tabular}{|c|c|c|c|c|c|c|c|c|c|c|c|c|}
\hline \multicolumn{2}{|c|}{ Plasma LH } & \multicolumn{2}{|c|}{ Plasma FSH } & \multicolumn{2}{|c|}{$\begin{array}{l}\text { Plasma test- } \\
\text { osteron }\end{array}$} & \multicolumn{4}{|c|}{ Plasma growth hormone } & \multicolumn{2}{|c|}{$\begin{array}{l}\text { Plasma } \\
\text { cortisol }\end{array}$} & \multirow[b]{2}{*}{ PBI } \\
\hline $\mathrm{C}$ & phene & $\mathrm{C}$ & $\begin{array}{l}\text { Clomi- } \\
\text { phene }\end{array}$ & c & HCG & $\mathrm{C}$ & $\mathbf{P}$ & ITT & ATT & $\mathrm{C}$ & $P$ & \\
\hline \multicolumn{2}{|c|}{$m I U / m l$} & \multicolumn{2}{|c|}{$m I U / m l$} & \multicolumn{2}{|c|}{$\mu g / 100 \mathrm{ml}$} & \multicolumn{4}{|c|}{$m \mu g / m l$} & \multicolumn{2}{|c|}{$\mu g / 100 \mathrm{ml}$} & $\begin{array}{c}\mu \mathrm{g} / \\
100 \mathrm{ml}\end{array}$ \\
\hline - & - & $<6.5$ & & 0.02 & 0.16 & 8 & 4 & 5 & 4 & 4 & 12 & 7.8 \\
\hline 14 & 18 & 4 & 5 & 0.01 & 1.53 & 2 & 1 & 2 & - & 2 & 2 & 3.0 \\
\hline 10 & 10 & 4 & 3 & 0.07 & 0.63 & 1 & 3 & 2 & 2 & 7 & 12 & 3.1 \\
\hline 8 & $<11$ & 4 & 4 & 0.02 & 0.12 & 2 & 3 & 3 & 2 & 1 & 3 & 3.0 \\
\hline 11 & 11 & 7 & 4 & 0.06 & 0.17 & 10 & 8 & - & - & 10 & 27 & 5.4 \\
\hline$<6$ & $<6$ & 7 & $<6$ & 0.07 & 0.14 & 1 & 1 & - & 1 & 13 & 27 & 4.0 \\
\hline$<11$ & $<11$ & 8 & 6 & 0.12 & 0.34 & 1 & 1 & 2 & 2 & 8 & 5 & 6.5 \\
\hline 6 & 6 & 6 & 5 & 0.20 & 0.70 & $<1$ & $<1$ & 3 & - & $8 \ddagger$ & 23 & 2.9 \\
\hline
\end{tabular}

somes. While this theory is applicable to many of the pedigrees of hypogonadism with defective olfaction and probably to the Laurence-Moon-Biedl syndrome, it may also explain cases such as these accumulated in the present report. Rigorous examination of this postulate in our patients is not possible, since other members of the kinships are not affected. However, it is noteworthy that chromosome number and morphology were normal in our subjects. Although this has been noted by others, our studies emphasize that sporadic cases of hypogonadism associated with hyposmia and somatic anomalies can occur in the absence of a family history.

Gonadotropin excretion. The onset of puberty is marked by an increase in gonadotropin and gonadal steroid secretion with subsequent development of secondary sexual characteristics. Therefore the clinical diagnosis of hypogonadotropic hypogonadism cannot be made until after the expected age of puberty, since children are by definition hypogonadal and hypogonadotropic. Although boys may undergo normal secondary sexual development after age 20 , clinical and laboratory features associated with hypogonadism may be noted by age 17 , if puberty does not occur $(31,32)$. These features include eunuchoidal body proportions, delayed bone age, small soft testes, and decreased development of androgen-dependent tissues and organs. In addition to these signs which are attributed to hypogonadotropism per se, our patients had hyposmia, bony anomalies, and cryptorchidism. These latter features make possible a presumptive diagnosis of hypogonadotropic hypogonadism even before the expected age of puberty.

Despite the clinical usefulness of the total gonadotropin assay it is inadequate for easy quantification at low levels. Recently the LH and FSH excretion of children has been determined by both bioassay and radioimmunoassay. These two assays gave comparable results and indicated that the concentrations of $\mathrm{LH}$ and $\mathrm{FSH}$ in the urine of normal children is one-tenth and one-half as much as that in normal adult males, respectively $(9,14$, 15). From our limited experience with hypogonadal subjects we would conclude that the urinary concentration of LH and FSH in some hypopituitary and hyposmic patients may be the same as those of normal children. Furthermore it is apparent that the hyposmic pa- 
TABLE III

Clinical and Laboratory Features of "Normal" Boys

\begin{tabular}{|c|c|c|c|c|c|c|c|c|c|}
\hline \multirow[b]{2}{*}{ No. } & \multirow[b]{2}{*}{ Patient } & \multirow[b]{2}{*}{ Age } & \multirow{2}{*}{$\begin{array}{l}\text { Bone } \\
\text { age }\end{array}$} & \multirow[b]{2}{*}{ Height } & \multirow[b]{2}{*}{ Weight } & \multirow{2}{*}{$\begin{array}{c}\text { Total gonado- } \\
\text { tropins }\end{array}$} & \multicolumn{2}{|c|}{ Plasma testosterone } & \multirow[b]{2}{*}{ Clinical features } \\
\hline & & & & & & & Control & HCG & \\
\hline & & $y r$ & $y r$ & $\mathrm{~cm}$ & kg & $M U / 24 \mathrm{hr}$ & $\mu g / 100 \mathrm{ml}$ & $\mu \mathrm{g} / 100 \mathrm{ml}$ & \\
\hline 16 & J. T. & 7 & 5 & 123 & 21 & $<10(1)^{*}$ & 0.04 & 0.17 & $\begin{array}{l}\text { Turner's phenotype (short } \\
\text { stature, web neck) }\end{array}$ \\
\hline 17 & K. P. & 8 & 8 & 126 & 30 & $<10(3)$ & & & Hypotonia \\
\hline & & & & & & $>10(1)$ & 0.02 & 0.28 & $\begin{array}{l}\text { Mental retardation } \\
\text { Cryptorchidism }\end{array}$ \\
\hline 18 & R. N. & 8 & 4 & 115 & 21 & $<10(4)$ & 0.03 & 0.20 & Short stature \\
\hline 19 & D. D. & 9 & 5 & 124 & 31 & $<10(1)$ & 0.03 & 0.41 & Short stature \\
\hline 20 & G. V. W. & 10 & 10 & 140 & 45 & $\begin{array}{l}<10(6) \\
>10(4)\end{array}$ & 0.04 & 0.23 & Small right inguinal testis \\
\hline
\end{tabular}

* Numbers of days assayed at this level.

tients cannot be distinguished from boys with delayed puberty on the basis of gonadotropin excretion.

Clomiphene citrate, an analogue of the nonsteroidal estrogen chlorotrianisene, increases $\mathrm{LH}$ and FSH secretion in normal but not in hypopituitary men $(18,19)$.

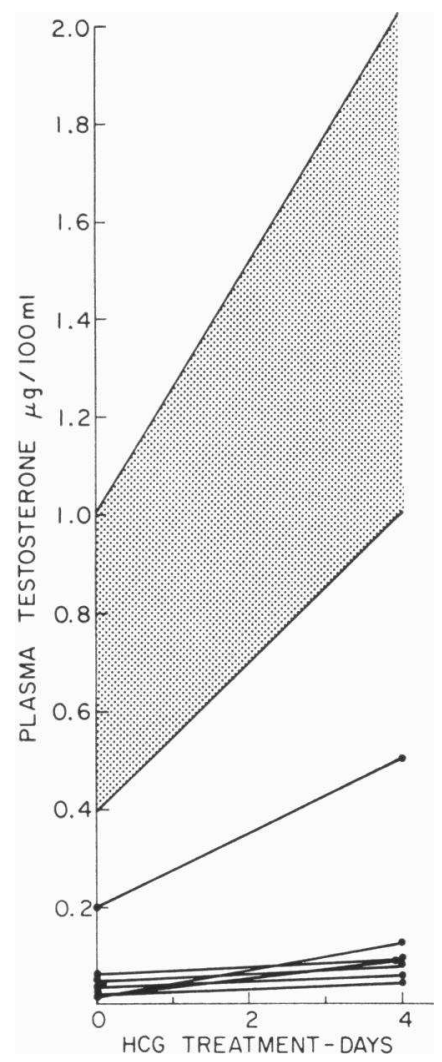

Figure 4 Plasma testosterone levels in hyposmic patients (solid lines) before and after human chorionic gonadotropin (HCG) administration. The range in normal men is given by the shaded area.

Bardin, Ross, Rifkind, Cargille, and Lipsett
It was therefore pertinent to investigate the effect of clomiphene on the plasma gonadotropin levels of the boys with hyposmia and hypogonadism. In five patients with low plasma testosterone levels increases of plasma $\mathrm{LH}$ and FSH were not observed, whereas patient No. 4 (plasma testosterone, $0.2 \mu \mathrm{g} / 100 \mathrm{ml}$ ) had a definite increase of plasma LH during clomiphene. These observations are in keeping with one theory proposed for clomiphene action which states that an antiestrogen (or antiandrogen) increases gonadotropin secretion by interrupting the negative feedback of gonadal steroids on the central nervous system. Since the hyposmic subjects

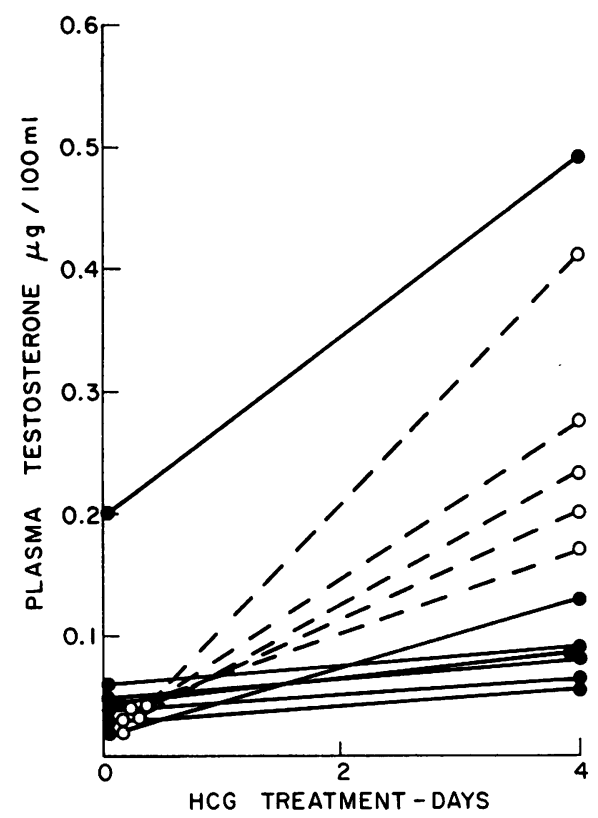

Figure 5 Plasma testosterone levels in hyposmic patients (solid lines) and "normal" boys (hashed lines) before and after HCG administration. 


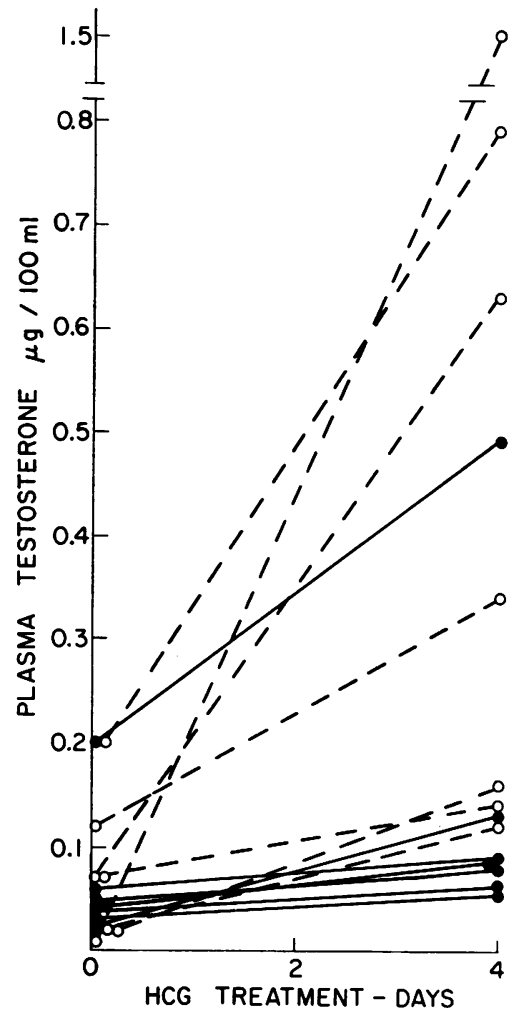

Figure 6 Plasma testosterone levels in hyposmic (solid lines) and hypopituitary patients (hashed lines) before and after HCG administration.

have not developed the normal negative feedback system, the low testosterone level fails to elicit an appropriate increase in plasma gonadotropins, and further interruption of androgen action on the brain by clomiphene does not facilitate $\mathrm{LH}$ and $\mathrm{FSH}$ secretion.

The hyposmic patients we have described have hypogonadotropism without any other detectable anterior pituitary hormonal deficiency. Whether the gonadotropin deficit is the result of an isolated pituitary abnormality or a defect in the central nervous system is not known with certainty. There is no direct evidence to suggest that an intrinsic abnormality of the gonadotropinproducing cell of the pituitary is responsible for the hypogonadotropism. Alternatively, the association of abnormalities in the central nervous system and hypogonadotropism suggests that they could be causally related. In this regard hypoplasia of the hypothalamus and mammillary bodies has been reported in several autopsied cases (33), but in these patients other parameters of pituitary function were not carefully assessed. Furthermore, the association of hypogonadotropism with hyposmia is even more intriguing since olfaction is necessary for sexual attraction and arousal in many species. The olfactory apparatus is phylogenetically part of the rhinencephalon, and the amygdaloid nuclei in this portion of the brain may be important for controlling the onset of puberty $(34,35)$. Thus a diffuse abnormality of rhinencephalic function could relate hyposmia and hypogonadotropism. However, the occurrence of hypogonadotropic hypogonadism alone and in association with a variety of other neurological defects indicates that the gonadotropin deficiency may occur independent of the hyposmia. Thus it would appear that an exact neuroanatomical correlation between an affected area of the brain and hypogonadotropism has not been established.

Testosterone secretion. During fetal life the testes secrete an androgen which is responsible for development of the external genitalia of the male. The presence of a normal phallus and scrotum in each of the hyposmic boys suggests that the gonad was active during fetal life. During the 1st yr of life the Leydig cells which are present at birth in the normal testes regress and are not usually recognizable histologically again until the time of puberty. The testes of patients with hypopituitarism and of the hyposmic boys were morphologically similar to those of the child, since Leydig cells were identified with difficulty. Reduced or "absent" Laydig cells is a common finding in patients with hypogonadotropic hypogonadism (31).

HCG has been used for many years as a test of Leydig cell function and for the treatment of secondary hypogonadism in man. Its efficacy is due to its ability to stimulate testosterone production (20). Several investigators have also shown that HCG can increase testosterone excretion in children (36-38). Stuiver, Thijssen, and Van der Molen (39) demonstrated a uniform increase in the plasma testosterone of boys (age 15-17 yr) with "delayed puberty," but there was a more variable response in hypopituitary patients. While it is impossible to compare quantitative results from two laboratories, it is noteworthy that these results are qualitatively similar to those obtained in our normal and hypopituitary patients. In the present study the response of the Leydig cells of three groups of hypogonadotropic subjects were compared. As a group the hyposmic boys were less responsive to 4 days of HCG than were the normal boys and hypopituitary patients.

Kallman et al (2) indicated that three of their patients with hypogonadism and anosmia failed to respond clinically to HCG administration, and there is brief mention of similar observations by several other investigators $(1,40,41)$, including a patient with Laurence-Moon-Biedl syndrome (24). Some of these reports are difficult to evaluate since no data are available to indicate that the gonadotropins administered produced a response in normal subjects. By contrast, Wieland, Folk, Taylor, and Hamwi (42) demonstrated, 


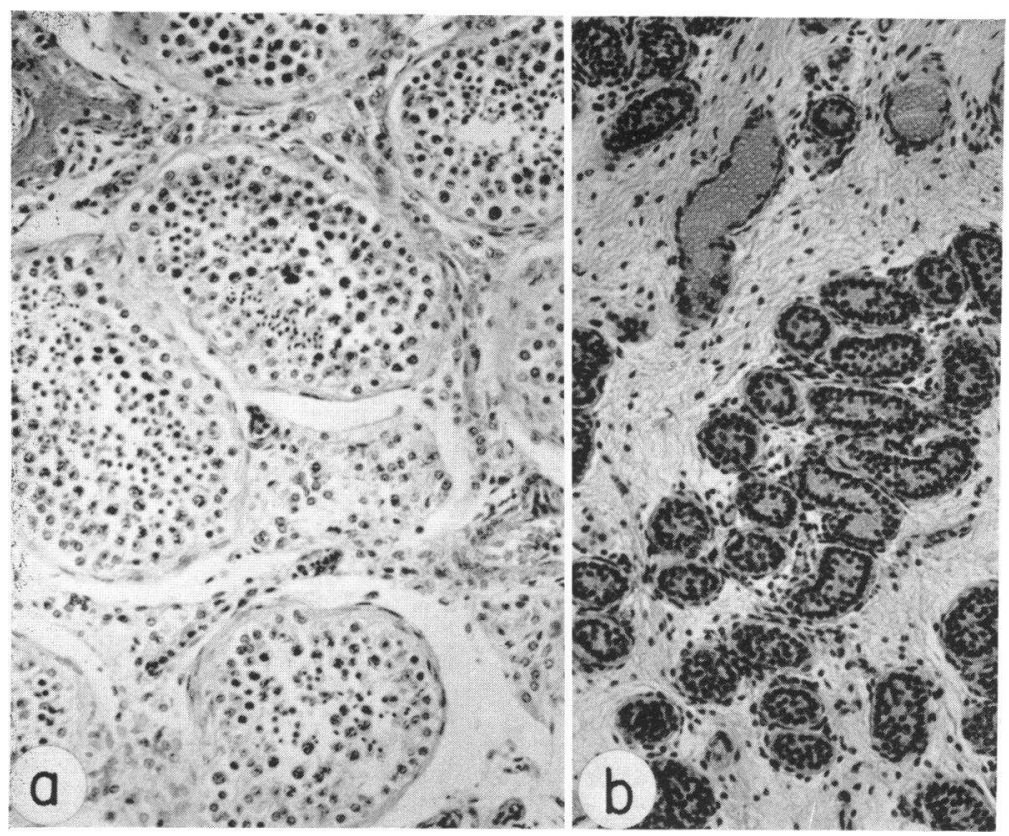

Figure $7 a$ Photomicrograph of normal testis from normal $28 \mathrm{yr}$ old man $H$ and $E, \times 150 . b$ Photomicrograph of testis from a patient (No. 5) with hypogonadotrophic hypogonadism and hyposmia. Note spermatogenic arrest and absence of Leydig cells. $H$ and $E, \times 150$.

by urinary testosterone excretion, that a patient with hypogonadism and gynecomastia responded less well to HCG than did two controls. In the present report the comparative studies of the plasma testosterone response to $\mathrm{HCG}$ provides the first quantitative evidence that the Leydig cells of hypogonadal boys with hyposmia are relatively insensitive to gonadotropins. The data available suggest that unresponsiveness of the Leydig cells in these patients is not a function of hypogonadotropism per se, since children and hypopituitary patients with similar gonadotropin levels showed a better response to HCG. Furthermore, some hyposmic patients failed to respond either clinically or with a normal testosterone increment to prolonged HCG administration. These observations are particularly significant since HCG treatment of prepuberal boys for 15 days increased plasma testosterone levels into the range of normal adult men (38). It would thus appear that the Leydig cell insensitivity represents a heretofore unemphasized gonadal abnormality in patients with hyposmia and hypogonadism. These patients may therefore have defects of both ends of the pituitary-Leydig cell axis manifested by hypogonadotropism and gonadotropin unresponsiveness.

\section{APPENDIX}

\section{Patients with hyposmia and hypogonadism}

Patient 1. J. S. had undescended testes at birth. $\mathrm{He}$ received injections of $\mathrm{HCG}$ at age 3 and $9 \mathrm{yr}$, and his left testes descended. At age $15 \mathrm{yr}$ he was again treated by his referring physician with HCG, 1500 IU three times weekly for 4 months. During this period of treatment he developed axillary, pubic, and facial hair and noted an increase in phallic size.

Patient 2. D. F. contracted chicken pox, bilateral otitis media, and pneumonia at 6 months of age. At $1 \mathrm{yr}$ he was noted to be deaf. Between the ages of 9 and $11 \mathrm{yr}$ he received several long courses of HCG for bilateral cryptorchidism. The testes did not descend, and axillary and pubic hair did not develop during HCG therapy. A right inguinal herniorrhaphy was performed at age $12 \mathrm{yr}$. At $14 \mathrm{yr}$ he was referred to us. He had nerve deafness, color blindness, left amblyopia exanopsia with heterochromia of irides, and decreased vision in the left eye. His penis was infantile, and there was no palpable prostate. The small right testis $(1 \times 1.5 \mathrm{~cm})$ was high in the inguinal canal, but the left testis was not palpable. Treatment with fluoxymestrone, $5 \mathrm{mg} /$ day, caused secondary sexual development.

Patient 3. H. C. was rejected by the army at age 18 because of failure to develop. The patient's father, however, had not undergone puberty until age $20 \mathrm{yr}$. He was referred to our service at age 20 at which time his penis and testes were infantile and the prostate was not palpable. After the studies were completed the patient received fluoxymestrone, $5 \mathrm{mg} /$ day, with adequate virilization.

Paticnt 4. $\mathrm{PH}$ was thought to have delayed sexual development at age $18 \mathrm{yr}$. Although he had erections, there were no ejaculations. At age $19 \mathrm{yr}$ he was referred to our service. He had an infantile penis and no palpable prostate. Testes measured $1 \times 1.5 \mathrm{~cm}$. $1 \mathrm{yr}$ after the tests were performed plasma testosterone was $0.04 \mu \mathrm{g} / 100 \mathrm{ml}$, and he complained of decreased libido. Fluoxymestrone, $5 \mathrm{mg} /$ day, caused adequate secondary sexual development and galactorrhea. 
Patient 5. N. W. did not walk until age 18 months and at $3 \mathrm{yr}$ was noted to be deaf. At age 22 he was referred to us because of sexual immaturity. He had nerve deafness and hyporeflexia. His penis $(5 \mathrm{~cm})$ and testes $(1 \times 2 \mathrm{~cm})$ were infantile, and there was no palpable prostatic tissue. After studies he was treated with HCG, 1000 IU three times weekly for 3 months followed by 4000 IU three times weekly for 2 months without detectable change in phallic or prostatic size. The plasma testosterone level after the second course of HCG was $0.23 \mu \mathrm{g} / 100 \mathrm{ml}$. The patient was then treated with fluoxymestrone and underwent secondary sexual development.

Patient 6. R. S. was treated with HCG at age $9 \mathrm{yr}$ for bilateral inguinal testes. During this therapy he noted growth of facial, axillary, and pubic hair which stopped when the HCG was discontinued. $\mathrm{He}$ subsequently had erections but no ejaculations. At age 23 he was referred to our service. His penis was $5 \mathrm{~cm}$ and scrotal testes were $1 \times 0.8 \times 0.5 \mathrm{~cm}$. No prostate tissue was palpable. The patient was then treated with HCG, 1000 IU twice weekly for 8 months. On this medication he noted gynecomastia, a slight increase in facial hair, and more frequent erections, but there were no ejaculations and no increase in prostate size. Plasma testosterone after 8 months of HCG therapy was $0.038 \mu \mathrm{g} / 100 \mathrm{ml}$.

Patient 7. H. R. was given a series of HCG injections for bilateral cryptorchidism at age $14 \mathrm{yr}$. On this medication the left testis descended into the scrotum, and there was an increase in stature ( 3 inches) and slight growth of both pubic hair and penis. Thereafter the patient did not undergo puberty, and there was no increase in height. At age $21 \mathrm{yr}$ he was referred to us. He had an infantile penis and testes and a small prostate. The right testis was high in the inguinal canal. HCG administration resulted in further growth of pubic hair, and penis and prostate increased in size. At age 22 after a right orchiopexy, fluoxymestrone ( $5 \mathrm{mg} /$ day) was begun, and secondary sexual development continued. At 27 yr of age fluoxymestrone was discontinued for 2 months, and the studies in Table I were performed.

\section{ACKNOWLEDGMENTS}

We wish to thank the following physicians for referring the hyposmic patients to our service: R. J. Meyer, T. Ham, I. M. Goldstein, R. H. Nestmann, J. J. Canary, R. R. Pittman, and J. Sode. We gratefully acknowledge the technical assistance of Amel French, Phil Rayford, and Jane Smith. We also thank Dr. Ralph Powell for preparing the photomicrographs.

\section{REFERENCES}

1. Pozanski, W. J., J. Bennett, and J. B. R. McKendry. 1967. Urinary steroid pattern in male hypogonadotropic hypogonadism. Can. Med. Ass. J. 96: 273.

2. Kallmann, F., W. A. Schonfeld, and S. E. Barrera. 1944. The genetic aspects of primary eunuchoidism. Amer. J. Ment. Defic. 48: 203.

3. Nowakowski, H., and W. Lenz. 1961. Genetic aspects in male hypogonadism. Recent Progr. Hormone Res. 17: 53.

4. Sparkes, R. S., R. W. Simpson, and C. A. Paulsen. 1968. Familial hypogonadotropic hypogonadism with anosmia. Arch Int. Med. 121 : 534.

5. Klinefelter, H. F., F. Albright, and G. C. Griswold. 1943. Experience with quantitative test for normal or decreased amounts of follicle stimulating hormone in urine in endocrinological diagnosis. J. Clin. Endocrinol. Metab. 3: 529.

6. Wilson, H., and M. B. Lipsett. 1963. Use of periodate oxidation in the clinical analysis of urine corticoids. Anal. Biochem. 5: 217.

7. Spencer-Peet, J., J. R. Daly, and V. Smith. 1965. A simple method for improving the specificity of the fluorometric determination of adrenal corticosteroids in human plasma. J. Endocrinol. 31: 235.

8. Odell, W. D., G. T. Ross, and P. L. Rayford. 1967. Radioimmunoassay for luteinizing hormone in human plasma or serum: physiological studies. J. Clin. Invest. 46: 248.

9. Cargille, C. M., D. Rodbard, and G. T. Ross. 1968. Radioimmunoassay of human follicle stimulating hormone: bias due to antisera. J. Clin. Endocrinol. Metab. 28: 1276.

10. Glick, S. M., J. Roth, R. S. Yalow, and S. A. Berson. 1963. Immunoassay of human growth hormone in plasma. Nature (London). 199: 784.

11. Bardin, C. W., and M. B. Lipsett. 1967. Estimation of testosterone and androstenedione in human peripheral plasma. Steroids. 9: 71 .

12. Steelman, S. L., and F. M. Pohley. 1953. Assay of the follicle stimulating hormone based on the augmentation with human chorionic gonadotropin. Endocrinology. 53: 604.

13. McArthur, J. W. 1952. The identification of pituitary interstitial cell stimulating hormone in human urine. Endocrinology. 50: 304.

14. Rifkind, A. B., H. E. Kulin, and G. T. Ross. 1967. Follicle-stimulating hormone (FSH) and luteinizing hormone $(\mathrm{LH})$ in the urine of prepubertal children. J. Clin. Invest. 46: 1925.

15. Kulin, H. E., A. B. Rifkind, and G. T. Ross. 1968. Human luteinizing hormone ( $\mathrm{LH}$ ) activity in processed and unprocessed urine measured by radioimmunoassay and bioassay. J. Clin. Endocrinol. Metab. 28: 543.

16. Kohler, P. O., B. W. O'Malley, P. L. Rayford, M. B. Lipsett, and W. D. Odell. 1967. Effect of pyrogen on blood levels of pituitary trophic hormones. Observations of the usefulness of the growth hormone response in the detection of pituitary disease. J. Clin. Endocrinol. Metab. $27: 219$.

17. Hembree, W. C., and G. T. Ross. 1969. Arginine infusion and growth hormone secretion. Lancet. 1: 52.

18. Bardin, C. W., G. T. Ross, and M. B. Lipsett. 1967. Site of action of clomiphene citrate in men: a study of the pituitary-Leydig cell axis. J. Clin. Endocrinol. Metab. $27: 1558$.

19. Cargille, C. M., G. T. Ross, and C. W. Bardin. 1968. Clomiphene and gonadotrophin in men. Lancet. 2: 1298.

20. Lipsett, M. B., H. Wilson, M. A. Kirschner, S. G. Korenman, L. M. Fishman, G. A. Sarfaty, and C. W. Bardin. 1966. Studies on Leydig cell physiology and pathology: secretion and metabolism of testosterone. Recent. Progr. Hormone. Res. 22: 245.

21. Frasier, S. D., and R. Horton. 1966. Androgens in the peripheral plasma of prepubertal children and adults. Steroids. 8: 777.

22. De Morsier, G. 1954. Etudes sur les dysraphies cranioencephaliques. Schweiz. Arch. Neurol. Psychiat. 74: 309.

23. Henkin, R. I. 1965. Hypogonadism associated with familial hyposmia. Clin. Res. 13: 244. (Abstr.) 
24. Warkany, J., G. S. Frauenberger, and A. G. Mitchell. 1937. Heredofamilial deviations. I. The Lawrence-Moon Biedl Syndrome. Amer. J. Dis. Child. 53: 455.

25. Roth, A. A. 1947. Familial eunuchoidism: The LawrenceMoon Biedl syndrome. J. Urol. 57: 427.

26. Volpé, R., W. S. Metzler, and M. W. Johnston. 1963. Familial hypogonadotrophic eunuchoidism with cerebellar ataxia. J. Clin. Endocrinol. Metab. 23: 107.

27. Matthews, W. B., and A. T. Rundle. 1964. Familial cerebellar ataxia and hypogonadism. Brain. 87: 463.

28. Lynch, H. T., A. R. Kaplan, M. J. Henn, and A. J. Krush. 1966. Familial coexistence of diabetes mellitus, hyperlipemia, short stature and hypogonadism. Amer. J. Med. Sci. 252: 323 .

29. Rosewater, S., G. Gwinup, and G. J. Hamwi. 1965. Familial gynecomastia. Ann. Int. Med. 63: 377.

30. Hecht, A., and H. Ruskin. 1960. Seminiferous tubule dysgenesis (Klinefelter's syndrome) associated with familial cerebellar ataxia. J. Clin. Endocrinol. Metab. 20: 1184 .

31. Albert, A. 1954. Male hypogonadism. IV. The testis in prepubertal or pubertal gonadotropic failure. Mayo Clin. Proc. 29: 131 .

32. Brasel, J. A., J. C. Wright, L. Wilkins, and R. M. Blizzard. 1965. An evaluation of seventy-five patients with hypopituitarism beginning in childhood. Amer. J. Med. 38: 484 .

33. Gauthier, G. 1960. La dysplasie olfacto-génitale (Agenesie des lobes olfactifs avec absence de développement gonadique à la puberté). Acta Neuroveg. 21 : 345 .

34. Elwers, M., and V. Critchlow. 1960. Precocious ovarian stimulation following hypothalamic and amygdaloid lesions in rats. Amer. J. Physiol. 198: 381.
35. Elwers, M., and V. Critchlow. 1961. Precocious ovarian stimulation following interruption of stria terminalis. Amer. J. Phy'siol. 201 : 281.

36. Knorr, D. 1968. Testosterone excretion in boys treated with HCG for cryptorchidism. In Testosterone. J. Tamm, editor. George Thieme Verlag KG, Stuttgart. 1st edition. 1 so.

37. Horton, R., F. Gaford, and S. D. Frasier. 1969. Plasma androgens in childhood and puberty. Clin. Res. 17: 106. (Abstr.)

38. Saez, J. M., and J. Bertrand. 1968. Studies on testicular function in children: plasma concentrations of testosterone, dehydroepiandrosterone and its sulfate before and after stimulation with human chorionic gonadotrophin. Steroids. 12: 749.

39. Stuiver, P. C., J. H. H. Thijssen, and H. J. Van der Molen. 1966. Plasma testosterone, urinary excretion of 17 ketosteroid fractions and urinary total 17 ketosteroids before, during and after stimulation with HCG in patients with deficient testicular function. In Androgen in Normal and Pathological Conditions. A. Vermeulen, editor. Excerpta Medica Foundation, Amsterdam. International Congress Series. 101: 87.

40. Hurxthal, L. M. 1943. Sublingual use of testosterone in 7 cases of hypogonadism: report of 3 congenital eunuchoids occurring in one family. J. Clin. Endocrinol. Metab. 3: 551 .

41. Muller, P. 1964. Die olfacto-genitale dysplasie. Gynaecologia. 158: 137.

42. Wieland, R. G., R. L. Folk, J. N. Taylor, and G. J. Hamwi. 1967. Studies of male hypogonadism. I. Androgen metabolism in a male with gynecomastia and galactorrhea. J. Clin. Endocrinol. Metab. 27: 763. 